\title{
Human Bocavirus Infection in Children with Acute Respiratory Infection in Nairobi, Kenya
}

\author{
Samwel Morris Lifumo Symekher ${ }^{1 *}$, George Gachara², James Maylor Simwa ${ }^{1}$, \\ Jane Gichogo ${ }^{1}$, Moses Rotich ${ }^{1}$, Musa Otieno Ng'ayo ${ }^{3}$, Japheth Magana ${ }^{1}$ \\ ${ }^{1}$ National Influenza Center, Center for Virus Research, Kenya Medical Research Institute (KEMRI), Nairobi, Kenya \\ ${ }^{2}$ Department of Medical Laboratory Sciences, Kenyatta University, Nairobi, Kenya \\ ${ }^{3}$ Center for Microbiology Research, Kenya Medical Research Institute (KEMRI), Nairobi, Kenya \\ Email: " slifumo@kemri.org, symolis@gmail.com, ggachara@gmail.com,msimwa@yahoo.com,jbarani@yahoo.com, \\ morotich@yahoo.com, musaotienong01@gmail.com,jmumagana@yahoo.com
}

Received August 27, 2013; revised September 27, 2013; accepted October 4, 2013

Copyright (C) 2013 Samwel Morris Lifumo Symekher et al. This is an open access article distributed under the Creative Commons Attribution License, which permits unrestricted use, distribution, and reproduction in any medium, provided the original work is properly cited. In accordance of the Creative Commons Attribution License all Copyrights (C) 2013 are reserved for SCIRP and the owner of the intellectual property Samwel Morris Lifumo Symekher et al. All Copyright (C) 2013 are guarded by law and by SCIRP as a guardian.

\begin{abstract}
Background: Acute respiratory infection (ARI) is a leading cause of morbidity and mortality in children under five years of age in developing countries with viruses contributing significantly to this problem. The recently identified parvovirus, Human Bocavirus (HBoV), has also been associated with ARI. Objective: To determine the frequency of $\mathrm{HBoV}$ in patients with ARI. Materials and Methods: Samples from 125 consenting patients with influenza like illness signs and symptoms were collected. DNA was extracted from these samples using the QIAamp DNA blood mini kit (Qiagen, Germany). Conventional PCR was carried out and the amplicons were examined in 2\% agarose gels stained with ethidium bromide. This was followed by sequencing of the HBoV positive samples. Results: Twenty one (16.8\%) patients were found to have $\mathrm{HBoV}$ infection. Males $(\mathrm{n}=61.9 \%)$ were mainly infected with $\mathrm{HBoV}$. Local HBoV strains had $98.9 \%-100 \%$ similarities and were found to cluster together with other strains obtained elsewhere. Conclusion: These findings suggest that $\mathrm{HBoV}$ plays a role in respiratory tract infections in children in Kenya just like it has been found elsewhere. It also sheds light on multiple infections associated with $\mathrm{HBoV}$ infections in Kenya.
\end{abstract}

Keywords: Acute Respiratory Infection (ARI); Human Bocavirus (HBoV); Polymerase Chain Reaction (PCR)

\section{Introduction}

Acute respiratory infection (ARI) is a leading cause of morbidity and mortality in children under five resulting in approximately 1.9 million of deaths worldwide annually $[1,2]$. Viruses such as respiratory syncytial virus (RSV), parainfluenza viruses (PIV), adenoviruses, rhinoviruses and influenza viruses are recognized as the most common etiologies of ARI. Other currently identified viruses among ARI patients include human metapneumovirus (HMPV) [3], severe acute respiratory syndrome coronavirus (SARS-CoV) [4] and the human bocavirus $(\mathrm{HBoV})[5,6]$.

The HBoV belongs to the genus Bocavirus of the Parvoviridae family and Parovirinae subfamily [5]. Coughing, wheezing, and fever are the most common clinical findings with bronchopneumonia and bronchioli-

"Corresponding author. tis being the most common ultimate diagnoses of $\mathrm{HBoV}$ infection. Since the first description of $\mathrm{HBoV}$ as a possible human pathogen of lower respiratory tract infections in children [6], $\mathrm{HBoV}$ has been detected in at least 19 countries in the five continents of Africa, America, Asia, Europe and Oceania infecting all persons with children and infants being the most susceptible [7,8]. This study sought to determine the frequency of $\mathrm{HBoV}$ in patients with signs and symptoms of ARI and also determine the genetic relationship of locally detected $\mathrm{HBoV}$ to other HBoV strains and prototype strains such as ST1 and ST2.

\section{Materials \& Methods}

\subsection{Sampling}

A total of 125 patients with signs and symptoms of acute respiratory infection participated in the study. Eligible 
patients were children aged $\leq 5$ years. They presented with a fever of more than $38^{\circ} \mathrm{C}$, chills, malaise, dry cough, and among other respiratory disturbances (running nose, sinusitis, epiglotitis, laryngitis). Consent was obtained from either the parents or guardians of the children enrolled to the study. Thereafter, throat/oropharyngeal swabs were collected and placed into cryovials containing an in house constituted virus transport medium (VTM). The swabs and VTM were then placed in cool boxes at $+4^{\circ} \mathrm{C}$ for transportation to the Kenya Medical Research Institute's (KEMRI), Acute Respiratory Infections (ARI) laboratory, based at the Center for Virus Research (CVR) in Nairobi, for storage at $-80^{\circ} \mathrm{C}$ until a time when processing was carried out.

\subsection{DNA/RNA Extractions}

Genomic DNA and RNA was extracted from $0.2 \mathrm{ml}$ of the collected throat/oropharyngeal swabs and stored in VTM using the QIAamp DNA blood mini (Qiagen, Valencia, CA, USA) and QIAmp viral RNA kit (Qiagen, Valencia, CA, USA) according to the kits manufactures' instructions.

\subsection{PCR Procedures}

\subsubsection{Detection of $\mathrm{HBoV}$ by Polymerase Chain Reaction (PCR)}

The extracted DNA $(5 \mu \mathrm{l})$ was used as a template for the PCR. The $50 \mu$ reaction mix consisted of $10 \times$ PCR buffer (Life Technologies, Carlsbad, CA), $50 \mathrm{mM}$ $\mathrm{MgSO}_{4}$ (Life Technologies, Carlsbad, CA), $2.5 \mathrm{mM}$ dNTPs (Life Technologies, Carlsbad, CA), AmpliTaq Gold DNA polymerase (Applied Biosystems). The $\mathrm{HBoV}$ was detected using primers targeting a $254 \mathrm{bp}$ region of the nonstructural 1 (NS1) gene

(Sense 5'-TATGGCCAAGGCAATCGTCCAAG-3' and antisense 5'-GCCGCGTGAACATGAGAAACAGA-3') [9]. The PCR procedure was carried out on AB 9700 PCR (GeneAmp ${ }^{\circledR}$ Applied Biosystem) and involved the following conditions; an initial PCR activation step at $95^{\circ} \mathrm{C}$ for 10 minutes followed by 45 cycles of $94^{\circ} \mathrm{C}$ for 30 seconds, $56^{\circ} \mathrm{C}$ for 30 seconds, and $72^{\circ} \mathrm{C}$ for 1 minute. Amplified products were detected using ethidium bromide stained 2\% agarose gel electrophoresis comparing the size of the amplicons to standard molecular markers.

\subsubsection{Detection of Influenza Viruses by Real Time reverse transcriptase $P C R$}

The influenza viruses in the samples were detected using a real time RT-PCR protocol designed and distributed by World Health Organization (WHO) and the Centers for Disease Control (CDC), USA [10] to National Influenza Centers worldwide. This was done on an AB 7500 Fast Real-Time PCR (Applied Biosystems).

\subsubsection{Sequencing and Phylogenetic Analysis}

The HBoV positive PCR products detected in this study were purified with ExoSap (Amersham Biosciences, Cleveland, $\mathrm{OH}$ ) to remove unincorporated primers and dNTPs and directly sequenced using the big dye terminator method in an ABI 3500 XL Genetic Analyzer (Applied Biosystems). Nucleotide sequences were assembled using BioEdit [11]. Phylogenetic trees were constructed by the neighbour-joining method and bootstrap analysis $(n=2000$ replicates $)$ to determine the best fitting tree for the NS1 gene using the method in the MEGA $^{\circledR}$ software version 5 [12]. Nucleotide sequences obtained from this study (JF313304-JF313321) were deposited to GenBank, a National Institute of Health (NIH) publicly available sequence database.

\section{Results}

Of the 125 patients recruited in the study period, 71 $(56.8 \%)$ were males while $54(43.2 \%)$ were females as shown in Table 1. The HBoV viruses were detected in $21(16.8 \%)$ samples out of the 125 samples tested in this study. There were also $20(16 \%)$ influenza A viruses (specifically influenza A (H1N1) pdm09 virus) detected in the same samples collected. No influenza B viruses were detected in the period of study. Of the $21 \mathrm{HBoV}$ positive samples, $12(61.9 \%)$ were detected in males while $9(38.1 \%)$ were detected in females. Most detections of $\mathrm{HBoV}$ were in the month of November $(\mathrm{n}=14$; $66.7 \%$ ) also shown in Table 1. Coinfections between $\mathrm{HBoV}$ and Influenza viruses were noted in only 3 (14.3\%) samples that had any virus detected in them.

The sequences of 18 out of the $21 \mathrm{HBoV}$ in this study were obtained, aligned and analyzed phylogenetically with HBoV prototype strains: ST1 and ST2 (GenBank accession numbers DQ000495 and DQ000496 respec-

Table 1. Distribution of $\mathrm{HBoV}$ positive specimens.

\begin{tabular}{|c|c|c|}
\hline \multicolumn{3}{|c|}{ Distribution of recruited patients gender $(n=125)$} \\
\hline & Frequency (n) & Percentage (\%) \\
\hline Males & 71 & 56.8 \\
\hline Female & 54 & 43.2 \\
\hline \multicolumn{3}{|c|}{$\begin{array}{l}\text { Distribution of recruited patients gender } \\
\text { with } \mathrm{HBoV} \text { detected }(\mathrm{n}=21)\end{array}$} \\
\hline Male & 12 & 61.9 \\
\hline Female & 9 & 38.1 \\
\hline \multicolumn{3}{|c|}{ Distribution of $\mathrm{HBoV}$ detected in the study period $(n=21)$} \\
\hline October & 4 & 19.0 \\
\hline November & 14 & 66.7 \\
\hline December & 3 & 14.3 \\
\hline
\end{tabular}


tively) and other similar $\mathrm{HBoV}$ strains obtained from GenBank as shown in Figure 1.

\section{Discussion}

This study aimed at determining the presence of the recently discovered $\mathrm{HBoV}$, together with influenza viruses from samples collected in an influenza sentinel surveillance program. The detection rate of $\mathrm{HBoV}$ infection in this study from children with ARI was $16.8 \%$ was higher than reports in a previous study in South Africa [14]. This detection rate in this study was however lower than that reported by a study carried out in Egypt. The differences between this study and the studies carried out in South Africa and Egypt could be due to the

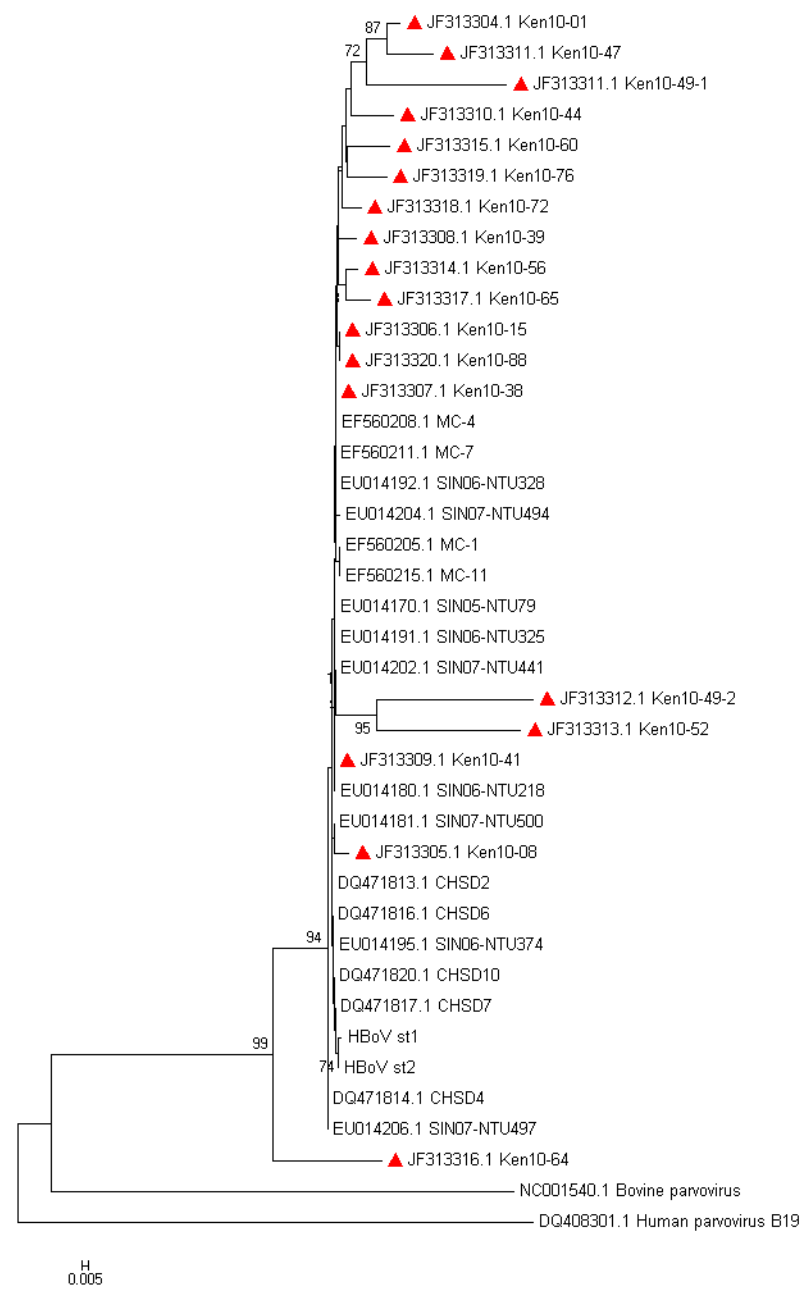

Figure 1. Evolutionary relationships of $\mathrm{HBoV}$. The evolutionary tree was inferred using the Neighbor-Joining method. The bootstrap consensus tree was inferred using 2000 replicates. The evolutionary distances were computed using the Kimura 2-parameter method [13]. The accession numbers of the Kenyan $\mathrm{HBoV}$ positive sequences are JF313304-JF313321, followed by the country (Kenya), year (2010) and laboratory identity. Evolutionary analyses were conducted in MEGA ${ }^{\circledR}$ software version 5. different sampling techniques. While the studies in South Africa and Egypt used samples from hospitalized patients, this study used outpatient samples. At the same time South Africa and Egypt tend to have a temperate climate in contrast to the tropic climate in Kenya. It has been shown previously that $\mathrm{HBoV}$ infection occurs predominantly during the winter season [14]. The detection rate of $\mathrm{HBoV}$ in this study however, is within range of other studies which have had a detection range of between $1.5 \%-19 \%[15,16]$.

Male patients $(\mathrm{n}=12 ; 61.9 \%)$ in this study had slightly more $\mathrm{HBoV}$ detections when compared to female patients. This observation has been noted in studies carried out in South America [17], Iran [18], Brazil [16] and in China [8]. This though is different from a study carried out in Saudi Arabia [19] where slightly more females were infected compared to males, and India [20] where both males and females were equally affected by HBoV. Coinfections of $\mathrm{HBoV}$ with other respiratory pathogens have been reported in other studies [8,21]. In this study, out of the 21 samples that had $\mathrm{HBoV}$ detected in them, only $3(14.3 \%)$ had coinfections of $\mathrm{HBoV}$ and influenza A (influenza $\mathrm{A}(\mathrm{H} 1 \mathrm{~N} 1) \mathrm{pdm} 09$ virus). The coinfection rates determined by this study are lower when compared to other studies which have reported coinfection rates of between $18 \%-72 \%[6,14,22]$. In countries with a temperate climate, $\mathrm{HBoV}$ frequently occurs during winter and early spring season $[6,16]$, while in South Africa, $\mathrm{HBoV}$ was detected throughout the year although most detections were in autumn and winter [14]. In our study, no clear seasonal distribution could be determined as the duration of this study (October to December) is too short to allow observation of any seasonal patterns. As a result more studies are required to determine the seasonal distribution of $\mathrm{HBoV}$ and its role together with other pathogens of the respiratory tract in disease severity.

All of the $18 \mathrm{HBoV}$ sequenced, $\mathrm{HBoV}$ aligned with the ST1 and ST2 reference strains, The multiple nucleotide sequence analysis showed an identity of $98.9 \%$ $100 \%$ amongst the circulating strains, thus indicating a low degree of genetic variability as described previously [23].

This study had several limitations. First, the study design used had a potential for sampling and selection bias of the patients. Second, the study was nested within an ongoing influenza surveillance study; the details of the patients' clinical information were not available. Due to this, we were not able to link the virus genetic data with the patients' clinical picture. Third, the study period was short which might given an underestimation of the true prevalence and seasonality of the $\mathrm{HBoV}$ detected in this population. Lastly, the detection panel used was not broad enough and a substantial number of potential copathogens were not be detected. 


\section{Conclusion}

In conclusion, despite the limitations of this study, these results provide important evidence that $\mathrm{HBoV}$ is involved in respiratory tract infection in Kenya. Additional studies will clarify not only the clinical and epidemiological significance of $\mathrm{HBoV}$ in the local population but also its presence in other clinical samples such as urine and stool specimens.

\section{Acknowledgements}

We acknowledge the Director of Kenya Medical Research Institute (KEMRI), Director of Center for Virus Research (CVR), and National Influenza Centre staff for facilitating this study. We wish to also acknowledge the staff in the sentinel surveillance sites for provision of samples for this study. This work is dedicated to the late former Head of the NIC-KEMRI, Dr. Walter Ochieng.

\section{REFERENCES}

[1] E. A. F. Simoes, et al., "Acute Respiratory Infections in Children," In: D. T. Jamison, et al., Eds., Disease Control Priorities in Developing Countries, 2nd Edition. World Bank, Washington DC, 2006, Chapter 25.

[2] B. G. Williams, et al., "Estimates of World-Wide Distribution of Child Deaths from Acute Respiratory Infections," The Lancet Infectious Diseases, Vol. 2, No. 1, 2002, pp. 25-32.

http://dx.doi.org/10.1016/S1473-3099(01)00170-0

[3] B. G. van den Hoogen, et al., "A Newly Discovered Human Pneumovirus Isolated from Young Children with Respiratory Tract Disease," Nature Medicine, Vol. 7, No. 6, 2001, pp. 719-724. http://dx.doi.org/10.1038/89098

[4] M. Chan-Yeung and W. C. Yu, "Outbreak of Severe Acute Respiratory Syndrome in Hong Kong Special Administrative Region: Case Report," BMJ, Vol. 326, No. 7394, 2003, pp. 850-852. http://dx.doi.org/10.1136/bmj.326.7394.850

[5] N. S. Young and K. E. Brown, "Parvovirus B19," The New England Journal of Medicine, Vol. 350, No. 6, 2004, pp. 586-597. http://dx.doi.org/10.1056/NEJMra030840

[6] T. Allander, et al., "Cloning of a Human Parvovirus by Molecular Screening of Respiratory Tract Samples," Proceedings of the National Academy of Sciences of the United States of America, Vol. 102, No. 36, 2005, pp. 12891-12896. http://dx.doi.org/10.1073/pnas.0504666102

[7] Z. Bi, P. B. H. Formenty and C. E. Roth, "Human Bocavirus, a Real Respiratory Pathogen," African Journal of Microbiology Research, Vol. 1, No. 5, 2007, pp. 51-56.

[8] L. S. Zheng, et al., "Human Bocavirus Infection in Young Children with Acute Respiratory Tract Infection in Lanzhou, China," Journal of Medical Virology, Vol. 82, No. 2, 2010, pp. 282-288. http://dx.doi.org/10.1002/jmv.21689

[9] F. Maggi, et al., "Human Bocavirus in Italian Patients with Respiratory Diseases," Journal of Clinical Virology,
Vol. 38, No. 4, 2007, pp. 321-325.

http://dx.doi.org/10.1016/j.jcv.2007.01.008

[10] CDC, "CDC Protocol of Realtime RT-PCR for Influenza A (H1N1)," 2010.

http://www.who.int/csr/resources/publications/swineflu/re altimeptpcr/en/index.html.

[11] T. A. Hall, "BioEdit: A User-Friendly Biological Sequence Alignment Editor and Analysis Program for Windows 95/98/NT," Nucleic Acids Symposium Series, 1999, pp. $95-98$.

[12] K. Tamura, et al., "MEGA5: Molecular Evolutionary Genetics Analysis Using Maximum Likelihood, Evolutionary Distance, and Maximum Parsimony Methods," Molecular Biology and Evolution, Vol. 28, No. 10, 2011, pp. 2731-2739. http://dx.doi.org/10.1093/molbev/msr121

[13] M. Kimura, "A Simple Method for Estimating Evolutionary Rates of Base Substitutions through Comparative Studies of Nucleotide Sequences," Journal of Molecular Evolution, Vol. 16, No. 2, 1980, pp. 111-120. http://dx.doi.org/10.1007/BF01731581

[14] H. Smuts and D. Hardie, "Human Bocavirus in Hospitalized Children, South Africa," Emerging Infectious Diseases Journal, Vol. 12, No. 9, 2006, pp. 1457-1458. http://dx.doi.org/10.3201/eid1209.051616

[15] H. O. Al-Rousan, et al., "Human Bocavirus in Jordan: Prevalence and Clinical Symptoms in Hospitalised Paediatric Patients and Molecular virus Characterization," Singapore Medical Journal, Vol. 52, No. 5, 2011, pp. 365369.

[16] A. K. Silva, W. A. de Mello, M. C. dos Santos and R. C. M. de Sousa, "Occurrence of Human Bocavirus Associated with Acute Respiratory Infections," Revista PanAmazônica de Saúde, Vol. 1, No. 1, 2010, pp. 87-92.

[17] G. Salmon-Mulanovich, et al., "Frequency of Human Bocavirus (HBoV) Infection among Children with Febrile Respiratory Symptoms in Argentina, Nicaragua and Peru," Influenza and Other Respiratory Viruses, Vol. 5, No. 1, 2011, pp. 1-5. http://dx.doi.org/10.1111/j.1750-2659.2010.00160.x

[18] M. Naghipour, et al., "Human Bocavirus in Iranian Children with Acute Respiratory Infections," Journal of Medical Virology, Vol. 79, No. 5, 2007, pp. 539-543. http://dx.doi.org/10.1002/jmv.20815

[19] A. S. Abdel-Moneim, et al., "Detection of Bocavirus in Children Suffering from Acute Respiratory Tract Infections in Saudi Arabia," PLoS One, Vol. 8, No. 1, 2013, Article ID: e55500.

http://dx.doi.org/10.1371/journal.pone.0055500

[20] P. Bharaj, et al., "Human Bocavirus Infection in Children with Acute Respiratory Tract Infection in India," Journal of Medical Virolog, Vol. 82, No. 5, 2010, pp. 812-816. http://dx.doi.org/10.1002/jmv.21637

[21] T. Ursic, et al., "Human Bocavirus as the Cause of a LifeThreatening Infection," Journal of Clinical Microbiology, Vol. 49, No. 3, 2011, pp. 1179-1181. http://dx.doi.org/10.1128/JCM.02362-10

[22] N. M. Kaplan, et al., "Human Bocavirus Infection among Children, Jordan,” Emerging Infectious Diseases Journal, 
Vol. 12, No. 9, 2006, pp. 1418-1420.

http://dx.doi.org/10.3201/eid1209.060417

[23] T. Chieochansin, et al., "Human Bocavirus (HBoV) in Thailand: Clinical Manifestations in a Hospitalized Pedi- atric Patient and Molecular virus Characterization," Journal of Infection, Vol. 56, No. 2, 2008, pp. 137-142.

http://dx.doi.org/10.1016/j.jinf.2007.11.006 